\title{
Contribution of Governance to Ensure the Stability of Islamic Banks: A Panel Data Analysis
}

\author{
Bakkeri Amine \\ Faculty of Economics and Management of Sfax \\ University of Sfax, Tunisia \\ E-mail: bakkeri.amine1@gmail.com
}

Received: June 28, 2018 Accepted: August 30, 2018 Published: September 3, 2018

doi:10.5296/ijafr.v8i3.13333 URL: https://doi.org/10.5296/ijafr.v8i3.13333

\begin{abstract}
The succession of crises imposed the need to establish the «Governance best practice ». This article tries to illustrate empirically the contribution of the mechanisms of the governance to ensure the stability of Islamic Financial Institutions. Using Zscore as a stability and solidity of IFI, our study focus on one sample of 30 Islamic banks taking place in 16 countries in North Africa and the Middle East shows that the size and the independence of the Board, the competence of the audit committee and the remuneration constitute the mechanisms helping to insure the stability of Islamic Financial Institutions. The duality seems to affect negatively the stability of the Islamic banks.
\end{abstract}

Keywords: Zscore, Islamic Bank, Governance mechanism, Stability, Panel Data

JEL Classifications: G21; G3; C20

\section{Introduction}

Due to the instability of the financial environment in these recent years, the Islamic finance is perceived as a real phenomenon that can solve this problem of instability using the adopting of the practices of good governance. Faced to this critical situation, the Islamic finance could record its strong presence by a remarkable resistance against the crisis that began in 2007 . Specialists and researchers in this field have questioned the reasons for which the model of Islamic industry establish the solution to ensure the stability of Islamic banks and that it can be a real alternative to the conventional system. In fact, the recent financial crisis has approved that the agency problems can be a source of instability. The remarkable phenomenon of the Islamic finance was not affected by the effects of this crisis (Asma Mghit; 
2013). Even there is a diversity of research working on Islamic finance, the attention is given mainly to issues related to the profitability (Sheila Nu Nu Htay (2012), Fadzlan Sufian and al (2010)), the governance (Abid A. Bukriet al (2014)). The financial products, the risk management ... the flap which in our case has remained unexplored even ignored the one related to the specificities of corporate governance and their input in the financial stability of Islamic banks.

Thus the first objective consists in studying the contribution of governance mechanisms to ensure the solidity and the stability of Islamic banks. To do so, the first section attempts to present a synthesis of the review of literature and the development of our research hypothesis. In the second section we present the methodology adopted in this research. The third section will present the results and interpretations of the economic analysis. The fifth section is devoted to our conclusions.

\section{Theoretical Frame Work and Research Hypothesis}

\subsection{Definition of the Concept of Governance}

The term of governance of companies "refers to the way in which the organization is managed or controlled". It includes all the policies and practices that affect the decision making of managers and contribute to how a company is perceived by current and potential players.

A set of rules that covers the duties, the obligations, the rights and the responsibilities of directors, the major shareholders and the company executives must be applied and respected by the various stakeholders.

According to Mustapha and Salleh (2002), the concept of governance in Islam means and traces the traits that God provides in people such as mainly the responsibility, the transparency and the reliability. By fostering a culture based on ethics and responsibility, the policies and the practices of good governance serves to increase the institution's value and to protect the interests of different stakeholders.

Suleiman (2005) indicates that the Islamic moral and religious aspects prevent the Muslims from behaving in opportunist manner.

This is an incentive mechanism to reduce the efficiency resulting from the asymmetric information and moral hazard.

\subsection{Specificities and Particularism of the Concept of Governance in the Islamic Context}

The new form of governance in the Islamic context includes the Anglo-Saxon model and the Sharia.

According to C ZIED and J.J Pluchart (2006) and Mohd Danial Afiq Khamar Tazilah and al (2014), the problem that shows in this level is that the leader is facing a plurality of governance rules like shareholders (Shareholders governance), partnership (Shareholders governance) and religious (Islamic governance) namely : 
Religious and ethical rules whose purpose is to ensure that transactions are conducted within the framework of the Shari'ah; Actionnariales and management of rules whose purpose is to protect the interests of shareholders; Rules of partnership which aims to discipline the leaders to act in the interests of different stakeholders.

In the Islamic context, even if the sources of instability (interest, debt instruments ....) Do not exist, the IFIs are encouraged to maintain customer confidence and enhance their reputation and credibility. Within these institutions is a Shari'ah Board Committee and an Audit Committee that is why they are doubly ruled.

\subsection{Governance Mechanisms in the IFIs}

\subsubsection{The Board of Directors}

The board of directors is an internal organ linked to the management and direction of the bank and it is composed of a specific number of members named by the general meeting of shareholders.

This board delegates some or all of its duties to a general director by means of the elections.

The literature records ambiguous results about the effect of the size of the board on the profitability and solidity of Islamic institutions. The arguments in the literature suggest that a larger board could be linked to a higher risk. In fact, Florackis and Ozkan (2004) reports that boards with more than seven or eight members are unlikely to be effective.

They further develop the Main Committees leading to a less effective coordination, the communication and decision making, and are more likely controlled by the chief executive officer. Huther (1997) says that the small tips seem to be more conducive to the involvement of members of the Board and therefore would result in a positive impact on the function of monitoring and strategic decision making capacity of the Board and independence from management. Aimen Ghaffar (2014) and Nadeem Ahmed Sheikh (2015) revealed a close and positive relationship between board size among Islamic banks in Pakistan. This positive effect is justified by increased experience of the majority of directors. In addition, Liang, and al. (2013) observed that the size board has an inverse relationship with the bank's performance. Based on the arguments discussed above, in our study, we want to test the following hypothesis:

\section{H1: the Board size has a significant influence in the stability of Islamic banks.}

\subsubsection{Independence of Members of the Board}

According to Azhar Abdul Rahman and al (2011), Choe \& Lee (2003) the composition of the board is very important to effectively monitor the managements and to reduce the cost of the agency. According to Sheila Htay $\mathrm{Nu}$ and al (2013), even so the independent directors have the skills, expertise and valuable knowledge of the operating policies of business and the day-specialized day, there is a need for independent directors contribute to new ideas, independence, objectivity and expertise gained from their own fields. Therefore, the agency theory recommends the involvement of non-executive directors to promote the independence 
of the Executive Board. Studies carried by Krivogorsky (2006), and Rebeiz and Salameh (2006) highlights the importance of independent directors and their effect on the financial position of institutions.

In the same vein, Aimen Ghaffar (2014) raised a positive relationship between the independence of members of the Board and the profitability of Islamic banks. This therefore affects the stability of these institutions. Liang, and al. (2013) by conducting a study in the Chinese context, have assumed a positive association between bank profitability and independence of board of directors. Based on the theoretical expectation, we test the hypothesis of a positive relationship between the stability of Islamic banks and the proportion of independent directors.

$\mathrm{H} 2$ : the independence of members of the Board has a positive influence on the stability of Islamic banks.

\subsubsection{The Committee of the Shariah Board}

Mahir Alman (2012) emphasized the beneficial role of this committee to know more experience, solidifying the reputation of Islamic banks and thus the conservation trust of various stakeholders.

This organization is interested in validating financial transactions and the newly innovated products of Islamic jurisprudence perspective. Abdelhalim gharbi and al (2014) mentioned the importance of the Shariah Committee as a factor that can affect the stability of Islamic banks. In their study, they have found a strong and positive relationship between the size of the Shari'ah supervisory board and bank profitability.

In his study, Ramiz and al (2010) indicates that the committee of Shari'ah has a considerable effect on bank profitability. Other studies such as Matoussi et al (2012) noted the absence of such a significant effect on the profitability of Islamic banks. From this work, we note that the literature records an ambiguous effect between profitability and the size of the Shariah Board Council. Our study suggests a favorable effect on the size of the Shariah Board Council and stability of Islamic banks. Like the discussed above, we test this hypothesis:

H3: the Committee of the Shari'ah Board positively affects the stability of Islamic banks.

\subsubsection{The Duality}

The separation of roles of the CEO and Chairman of the Board in relation to the profitability of financial institutions was the subject of several research projects namely Azhar Abdul Rahman et al (2011), Sheila $\mathrm{Nu} \mathrm{Nu}$ Htay and al (2013). These postulate that a separate management structure is recommended to monitor the CEO objectively and effectively.

In the same vein, Norlizan MAT RABI (2010), Kula (2005) and Rebeiz and Salameh (2006) assert the existence of a positive relationship between the separate management structure and profitability. Others like Maria Praptiningsih (2009) highlight a negative effect.

The agency theory emphasizes the importance of the independence of the Executive Board through a separate management structure. The findings of Azhar Abdul Rahman et al (2011) 
are in agreement with theoretical expectations, namely a positive relationship between the separate management structure and performance. According Htay et al (2013) this separate management structure raises the degree of transparency and reflects the adoption of governance best practices. The positive effects of the separation of the two roles are canceled by the slow decision making processes that are better addressed if the two roles are combined.

Like the work of Hamadi Matoussi and Rihab Grassa (2012), duality is a significant and positive impact to profitability of Islamic banks.

H4: The duality has an effect on the profitability and hence the stability of Islamic banks.

\subsubsection{Remuneration Policy}

Creating a favorable environment to improve opportunities for development and growth of Islamic banks seems to be linked to an effective compensation system. Most previous studies found that there is a positive relationship between pay and corporate performance (Kakabadse \& Kakabadse, 2001; Brick, Palmon and Wald, 2006; Aggarwal and Samwick, 2006). Brick, Palmon and Wald (2006) explain that the compensation is a source of motivation for directors and officers to improve business performance. Lee and Isa (2015), Nadeem Ahmed Sheikh et al (2015) generated a positive effect between the remuneration of the CEO and the profitability of Islamic banks. We test the hypothesis:

H5: compensation has a positive effect on the stability of the Islamic financial institutions.

\subsubsection{Ownership Structure}

The ownership structure has been widely used as a variable linked to the bank and explanatory governance bank profitability whether Islamic or conventional. In their work on the effect of governance practices on the profitability of Islamic banks, Achour Chawki et al (2015) have suggested a negative relationship between ownership structure and the profitability of Islamic banks. Al-Saidi and Al-Shammari (2015) evoked a negative relationship between ownership structure within firms and profitability. In the same vein, and Fooladi Foroughi (2012) in the context of Tehran showed a negative effect of ownership structure on profitability. This result is confirmed by Tomar and Bino (2012) in his study in the Jordanian context.

H6: The ownership structure has a significant impact on the stability of BI.

\subsubsection{The Competence of the Members of the Audit Committee}

Audit committees are subcommittees of the Board whose responsibilities include overseeing the financial reporting process and the validity of the operations as planned and the audit financial Islamic financial institutions. After all, members of such a financial institution must meet conditions such as transparency, independence and competence. The impact and contribution of the competence of the members of this committee to ensure the profitability and stability of banks was the subject of several studies which like Azhar Abdul Rahman and al (2011). The Audit Committee is established in order to build confidence in the integrity of the process and procedures of the organization's internal controls, including financial 


\section{MlMacrothink}

International Journal of Accounting and Financial Reporting

ISSN 2162-3082

2018, Vol. 8, No. 3

information. According to Gagan Kukreja (2013), the Audit Committee is a reassuring factor the board through its oversight and monitoring. The literature indicates that the agent main problem gives rise to agency costs resulting from opportunistic behavior and the maximization of wealth at the expense of others. The audit committee is one of the governance mechanisms used to neutralize the agency costs and it is a stabilizing factor for the IFIs. According to the work discussed above, the competence of audit committees is enhanced by the existence of an expert to the audit committee or the Shariah Board Committee.

H7: The competence of the audit committee has a significant effect on the financial stability of Islamic banks.

\subsubsection{Economic Crisis}

Abaoub and al (2008) reported in their study that corporate governance can address the economic crisis. Similarly, Mo'taz Amin Al-Sa'eed (2012) in his study dealt with the role of governance in reducing banking crises. These studies have addressed the role of corporate governance as a factor for resolving economic instability even avoiding repel attacks during the critical moments. We try to test the hypothesis :

H8: In times of crises, Islamic banks are strong and stable.

\section{Research Methodology}

\subsection{Sample}

Our sample consists of 25 Islamic banks operating in 16 countries in North Africa, Middle East and South East. The variables constituting our model are retrieved from the database Bancscoupe and annual reports published by Islamic banks concerned.

\subsection{Research Model and Measurement of the Variables}

Like the works from the literature, we propose to study the following model:

$$
\begin{aligned}
& \text { Zscore }_{\text {it }}=\beta_{0}+\beta_{1} \text { Board SIZE }_{\text {it }}+\beta_{2} \text { AD-IND }_{\text {it }}+\beta_{3} \text { BSSB }_{i t}+\beta_{4} \text { AUD COM }_{i t}+\beta_{5} \text { CEO } \\
& \text { DUALY }_{\text {it }}+\beta_{6} \text { OWN STR }_{i t}+\beta_{7} \text { CRISES }_{i t}+\beta_{8} \text { RUMUN }_{\text {it }}+\beta_{9} \text { SIZE }_{\text {it }}+\beta_{10} \text { AGE }_{i t}+\varepsilon_{i t}
\end{aligned}
$$

\subsubsection{Dependent Variable}

Zscoreit: Variable expressing the bank's stability $i$ at time $t$. It is calculated by the sum of the average return on assets (ROA) and equity as a percentage of total assets (FP / Total Assets) divided by the standard deviation of the return on assets (ROA) expressing the volatility of returns Cihak and Hesse (2008).

$$
\begin{gathered}
\text { ZScore }=\text { - } \mathrm{ROA}_{\mathrm{it}}+\left(\mathrm{FP}_{\mathrm{it}} / \mathrm{Ttotal} \text { Actifs }_{\mathrm{it}}\right) \\
\sigma(\mathrm{ROAit})
\end{gathered}
$$




\section{Mll Macrothink}

With:

ROA: means the average return on assets of Islamic banking. (ROA).

FP: the equity in $\%$ of total assets.

$\sigma:$ the standard deviation of ROA designating the volatility of returns.

According to Cihak and Hesse (2008), the probability of insolvency is interpreted as the probability of instability or bankruptcy. Which means $\pi$ losses are greater than Equity in a way the following equation holds:

$$
\mathrm{P}(\pi \leq-\mathrm{FP})=\mathrm{P}\left(\operatorname{Prob}[\mathrm{ROA} \leq-(\mathrm{FP} / \mathrm{ROA})]=\int_{-00}^{-(\text {FP/ROA) }} f(R O A) d(R O A)\right.
$$

In his study, De Nicolo (2000) indicates that the probability of bankruptcy or loss is equal to the inverse square of Zscore.

$$
\begin{aligned}
& \sigma^{2}(\mathrm{ROA}) \\
& \mathrm{P}(\pi \leq-\mathrm{FP})=\mathrm{P}(\operatorname{Prob}[\mathrm{ROA} \leq-(\mathrm{FP} / \mathrm{ROA})] \leq \quad--- \\
& {[\mathrm{ROA}+(\mathrm{FP} / \mathrm{ROA})]^{2} \quad(\text { Zscore })^{2}}
\end{aligned}
$$

The z-score measures the number of standard deviations of return achievement must fall to deplete equity, under the assumption of normality of banks' returns. A higher z-score is alower probability of insolvency risk.

\subsubsection{Independent Variables}

Board size $\mathrm{it}_{\mathrm{it}}$ explanatory variable denoting the size of the board. It is measured by the number of members of the bank's board $i$ at time $t$.

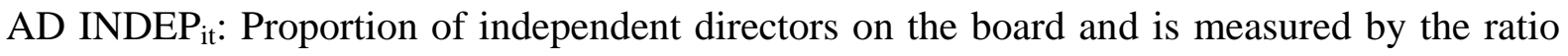
of independent members to the total of the Bank's members $i$ at time $t$.

$\mathrm{SSB}_{\mathrm{it}}$ : Variable that identifies size of the Compliance Committee as measured by the number of members on the Board Shari'a Board of the bank i at time t.

AUD $\mathrm{COM}_{\mathrm{it}}$ : binary variable that takes the value of the unit if it includes an expert committee among its members; 0 if not.

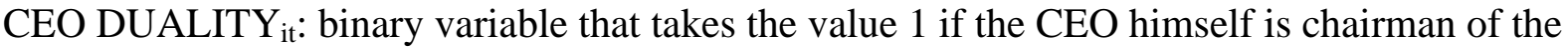
bank's board $i$ at time $t$ ie combination of missions, 0 if not.

OWN STRU $\mathrm{it}_{\mathrm{it}}$ : Part of shares held by major shareholders in the bank $\mathrm{i}$ at time $\mathrm{t}$.

CRISES $_{\text {it }}$ : binary variable that takes the value of the unit if it is crisis period; 0 if not.

REMUN $_{\text {it }}$ : variable that indicates the executive compensation calculated by the ratio between variable between year $t$ and $t-1$ and that the total remuneration in the bank $i$ at time $t$. 


\section{Al Macrothink}

International Journal of Accounting and Financial Reporting

ISSN 2162-3082

2018, Vol. 8, No. 3

\subsubsection{Variables of Control}

SIZE $_{\mathrm{it}}$ : Variable designating the bank size $\mathrm{i}$ at time $\mathrm{t}$ and is expressed by the logarithmic value (natural $\log$ ) of Total Assets.

$\mathrm{AGE}_{\mathrm{it}}$ : Variable measuring the age and is expressed by the number of years from its establishment of the bank $i$ at time $t$.

Like the work of Asma Bkhit (2013), and others, we call upon the generalized least square method (GLS) as existing in the literature to enhance our empirical study on the contribution of corporate governance in explaining the stability of Islamic financial institutions. According to Gujarati (2003), the use of this method allows us to overcome the problems of heteroscedasticity or multicolinearity or both at once. The test of Haussman allows us later to choose between the fixed effect or the random effect.

Thus, our econometric specification takes the following form:

$$
\text { Zscore }_{i t}=\alpha_{i}+\beta X_{i t}+£ M_{i t}+p K_{i t}+U_{i t}
$$

where:

Zscore: means the dependent variable (Stability of Islamic banks).

$\mathrm{X}_{\mathrm{it}}$ : means the vector of variables related to corporate governance in Islamic banks.

$\mathrm{M}_{\mathrm{it}}$ : means the vector of environment-related variables in which Islamic banks operate.

$\mathrm{K}_{\mathrm{it}}$ : means the vector of control variables.

$\mathrm{U}_{\mathrm{it}}$ : the error term or disturbance.

\section{Results and Interpretations}

\subsection{Econometric Tests}

The Test of Haussman allows us to inquire if both estimators are statistically different. In fact the probability of this test (Pvalue $=0,461$ ) is more than $10 \%$ which implies that the random effect is better than the fixed effect. In the same context, this study records the presence of heteroscedasticity, so we had to use the method of standard errors corrected for data Panel (Panel Corrected Standard Erros) to address the problem of heteroscedasticity. 


\subsection{Descriptive statistics and Correlation Matrix for Pearson}

Table 1. Descriptive statistics

\begin{tabular}{lllll}
\hline Variables & Min & Mean & Max & SD \\
\hline Z score & 0.321 & 53.363 & 297.456 & 81.454 \\
\hline Board Size & 4 & 10.045 & 17 & 2.99 \\
\hline AD Indep & 0.21 & 0.39 & 0.58 & 0.113 \\
\hline OWN- STR & 0.2 & 0.322 & 0.47 & 0.076 \\
\hline SBS & 2 & 3.615 & 5 & 0.990 \\
\hline Audit COM & 0 & 0.26 & 1 & 0.434 \\
\hline CRISEES & 0 & 0.25 & 1 & 0.434 \\
\hline CEO DUAL & 0 & 0.335 & 1 & 0.473 \\
\hline RUMUN & 0.11 & 0.212 & 0.38 & 0.071 \\
\hline SIZE & 5.919 & 7.584 & 8.297 & 1.969 \\
\hline AGE & 9 & 16.26 & 30 & 7.028 \\
\hline
\end{tabular}

The size of the board registers an average of 10,045 even a minimum of 4 and a maximum of 17 involving the idea in which the more the size is little the more the board will be effective in completing his missions. The variable related the independence of the board members indicates that on average there are $39 \%$ of members who are independent, even a $21 \%$ minimum of independence and a maximum level of $58 \%$. This statistic illustrates a justification for the transparency and independence of the board. The major shareholders hold on average $32 \%$ of the shares is a maximum level of $47 \%$ of the total shares. This gives us indication that they are not able to influence decisions in their own interests. With 4 members, the Board may audit the business and affairs of the bank point of view of Shariah and allows ignoring the problems of poor coordination or consistency or inconsistency say. Executive compensation records an average of $21.2 \%$ of the total of distributed earnings, a minimum of $11 \%$, a maximum level of $47 \%$ and a standard deviation of 0.071 . These data tell us about the importance given to the remuneration of staff employed in Islamic banks. Duality designating the leadership structure saves an average of $33.5 \%$ of Islamic banks opting a combined structure and a standard deviation of 0.473 . 


\section{MlMacrothink}

International Journal of Accounting and Financial Reporting

ISSN 2162-3082

2018, Vol. 8, No. 3

Table 2. Correlation matrix

\begin{tabular}{llllllllllll}
\hline Variables & Z & Board & AD-I & OW_ & SBS & Audit & CEO & CRIS & RUM & SIZE & AGE \\
& score & Size & ND & STR & & COM & dUAL & EE & UN & & \\
& & & & & & & &
\end{tabular}

Z score $\quad 1$

$\begin{array}{lll}\text { Board } & 0.37 & 1 \\ \text { Size } & 9 & \end{array}$

$\begin{array}{llll}\text { AD-IND } & 0.09 & -0.088 & 1\end{array}$

$\begin{array}{lllll}\text { OWNR_S } & -0.11 & -0.056 & 0.132 & 1 \\ \text { TR } & 2 & & \end{array}$

\begin{tabular}{|c|c|c|c|c|}
\hline SBS & $\begin{array}{l}0.62 \\
0\end{array}$ & 0.426 & -0.273 & -0.076 \\
\hline
\end{tabular}

\begin{tabular}{lllllll}
\hline AUDIT & 0.75 & 0.222 & -0.172 & -0.036 & 0.595 & 1 \\
COM & 0 & & & &
\end{tabular}

$\begin{array}{llllllll}\text { CEO } & -0.10 & -0.057 & 0.022 & 0.054 & -0.032 & -0.118 & 1 \\ \text { DUAL } & 7 & & & & & \end{array}$

$\begin{array}{lllllllll}\text { CRISEES } & -0.11 & -0.079 & 0.004 & 0.015 & -0.004 & -0.066 & -0.034 & 1\end{array}$

$\begin{array}{llllllllll}\text { RUMUN } & 0.04 & -0.034 & 0.002 & 0.035 & -0.064 & -0.059 & -0.016 & 0.013 & 1\end{array}$

\begin{tabular}{|c|c|c|c|c|c|c|c|c|}
\hline SIZE & $\begin{array}{l}0.02 \\
5\end{array}$ & 0.055 & 0.022 & 0.030 & -0.000 & 0.053 & 0.027 & $\begin{array}{ll}-0.112 & -0.014\end{array}$ \\
\hline
\end{tabular}

$\begin{array}{llllllllllll}\text { AGE } & 0.15 & -0.026 & 0.044 & -0.032 & 0.016 & 0.027 & -0.028 & 0.086 & 0.020 & -0.076 & 1\end{array}$

The independent variables of our model, resulting from the correlation matrix of Pearson, show the absence of a strong correlation between these variables. We note that no serious problem is detected of correlation between variables. The study of the Pearson correlation matrix shows that the correlation coefficients between the variables are less than 0.8 (Kennedy, 2003). 


\subsection{Econometric Estimation Model and Interpretations of the Results}

Table 3. Multivariate regression analysis

\begin{tabular}{lllll}
\hline Variables & sign Predicts & Coef. & t- statistics & significance \\
\hline Constante & & -1.906 & -2.63 & $0.009 * * *$ \\
\hline Board Size & $-/+$ & 0.818 & 3.61 & $0.000^{* * *}$ \\
\hline AD-IND & + & 2.08 & 1.68 & $0.092^{*}$ \\
\hline OWN STR & - & -1.226 & -1.63 & $0.103(\mathrm{n} / \mathrm{s})$ \\
\hline SBS & + & 0.820 & 3.58 & $0.000^{* * *}$ \\
\hline Audit COM & + & 7.419 & 11.66 & $0.000^{* * *}$ \\
\hline CRISEES & - & -0.049 & -0.38 & $0.703(\mathrm{n} / \mathrm{s})$ \\
\hline CEO DUAL & $-/+$ & -0.059 & -1.78 & $0.076^{*}$ \\
\hline RUMUN & + & 0.016 & 2.80 & $0.005^{* *}$ \\
\hline SIZE & $-/+$ & -0.011 & -0.24 & $0.808(\mathrm{n} / \mathrm{s})$ \\
\hline Age & + & 1.228 & 3.19 & $0.001 * * *$ \\
\hline
\end{tabular}

Number of Islamic banks: 25

Number of observations: 200

prob $>$ Chie $2=00.000$

$*, * *, * * *$ : The coefficients are significant at the thresholds of $10 \%, 5 \%$ and $1 \%$, respectively

The estimation of regression has produced the following results:

The coefficient of the board size is positive and significant at the $1 \%$ level $(\mathrm{P}>|\mathrm{Z}|=0.000)$. This result can be explained by the fact that the number of Board of directors is deemed important enough to perform a strict control in order to achieve the objectives of profitability and therefore stability. Board members must have knowledge and skills to make better decisions to improve the bank's credibility.

The coefficient of the independence of board members of administration is positive and significant at the $5 \%$ level $(\mathrm{P}>|\mathrm{Z}|=0.050)$. Independence is one of the criteria that must 


\section{Mll Macrothink}

International Journal of Accounting and Financial Reporting

ISSN 2162-3082

2018, Vol. 8, No. 3

have such a board and is an element of transparency and demarcation conflicts of interest and serves to reduce agency costs and opportunistic behavior.

The coefficient on the variable denoting the ownership structure on the stability and financial strength of Islamic banks is negative but not significant $(P>|Z|=0.103)$. This result is not consistent with our theoretical expectation.

The sign of the variable denoting the Shari'ah supervisory board size is statistically significant and positive at the $1 \%$ level $(\mathrm{P}>|\mathrm{Z}|=0.000)$. This is consistent with theoretical expectations. The Sharia Board is an instrument of stability and profitability to maintain customer confidence, strengthen the reputation of the bank which translates into increased productivity and stability. The effect of the Shari'a Supervisory Board can be derived through two roles namely supervisory role of the various financial transactions and advisory role having link with the validity of transactions following the Shariah.

The coefficient of the variable on the competence of the Member of the Audit Committee appears to be largely positive and significant at the $1 \%$ level $(P>|Z|=0.000)$. This significant effect may be interpreted by the fact that the existence of an expert in finance field and accounting to the Audit Committee strengthens the informational quality and the quality of financial statements.

The coefficient of duality seems to be negative and significant at the $10 \%$ level $(\mathrm{P}>|\mathrm{Z}|=$ 0.076). This result confirms our hypothesis and validates our theoretical expectations. According to Htay and al (2013) this separate management structure raises the degree of transparency and reflects the adoption of governance best practices. Our results corroborate the results of Maria Praptiningsih (2009) that support the idea that the combined structure of these roles leads to the presence of the dominant personality. This one could disrupt the flow of information to the public, transparency and can threaten the credibility of the banks and therefore their stability.

Variable crises coefficient is negative and not significant $(P>|Z|=0.703)$. This is consistent with theoretical expectations in the context of Islamic banks.

The literature indicates that the outbreak of financial crisis constitute a burden on the whole economy generally. In this concept, Hatem Hatef Abdulkadhim Altaee and al (2013) point out that the establishment of governance mechanisms within conventional banks can overcome the banking crisis problem.

The coefficient on the variable designating the compensation is positive and significant at the $1 \%$ level $(\mathrm{P}>|\mathrm{Z}|=0.005)$. The compensation affects positively the stability of Islamic banks. The sign of this variable is consistent with theoretical expectations and our hypothesis is confirmed. The objective of profitability and stability can be achieved through a system of remuneration that motivates different employees to use their skills to the welfare of the institution. 


\section{Macrothink}

International Journal of Accounting and Financial Reporting

ISSN 2162-3082

2018, Vol. 8, No. 3

The coefficient on the variable designating the bank size is not significant and is negative. The literature records complex and ambiguous results. Bikker and al (2002), Muzafar Shah Habibullah and al (2014).

The coefficient of the age variable is positive and significant at the $1 \%$ level $(\mathrm{P}>|\mathrm{Z}|=$ 0.008). The age of the bank tells us the degree of adaptation of the bank with its environment. In fact, such an institution seeks to achieve a considerable level in terms of profitability and stability through its experience.

\section{Conclusion}

This study attempts to empirically study the contribution of governance mechanisms to ensure the solidity and stability of Islamic banks. To answer this question, we conducted our study on a sample of 25 Islamic banks operating in the Middle East region. We applied the Standard Errors Corrected method for panel data to address problems of heterosedasticity.

Our results released shows that the independence and the size of the board, the size of the Sharia Supervisory Board, the competence of the audit committee, the remuneration favor stability of Islamic Banks while the structure property and duality seem to negatively affect the stability of the IFIs.

We can conclude that a banking environment is characterized by a strong and an effective governance system that takes into account the specificities of Islamic banks which are liable for financial stability and ensure the profitability and survival of these institutions.

Our study suffers some limitations that mainly the size of the sample found to be a bit low and the unavailability of all required data. However to extend and to deepen our work, it is useful to integrate other variables related to the risk management and to the profitability.

\section{References}

Aggarwal, R., \& Samwick, A. (2006). Empire-Builders and Shirkers: Investment, Firm Performance, and Managerial Incentives. Journal of Corporate Finance, 12, 489-515.

Alman, M. (2012). Shari'ah supervisory board composition effects on Islamic banks' risk taking behavior. European Financial Management Association meeting 2012.

Al-Sa'eed, M. A. (2012, March).The Role of Corporate Governance on the Reduction of the GlobalFinancial Crisis Implications: Evidence from Banking Sector of Jordan. International Journal of Business and Management, 7(5).

Al-Saidi, M., \& Al-Shammari, B. (2015). Ownership concentration, ownership composition and the performance of the Kuwait listed non-financial firms. International Journal of Commerce and Management.

Altaee, H. H. A., Talo, I.M. A., \& Adam, M. H. M. (2013). Testing the Financial Stability of Banks in GCC Countries: Pre and Post Financial Crisis. International Journal of Business and Social Research (IJBSR), 3(4). 


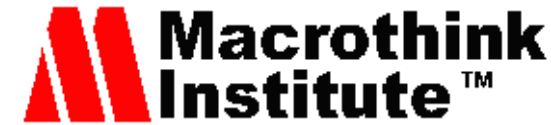

International Journal of Accounting and Financial Reporting

ISSN 2162-3082

2018, Vol. 8, No. 3

Bikker, J. A., \& Haaf, K. (2002). Competition, Concentration and Their Relationship: An empirical Analysis of the Banking Industry. Journal of Banking and Finance, 26, 2191-2214.

Bkhit, A. (2013, December). La solidité des banques islamiques et conventionnelles durant la crise financière de 2007-2008, Deuxième forum international de l'industrie financière islamique; Mécanismes de rationalisation de l'industrie financière islamique, 8(9).

Brick, P., \& Wald (2006, June). CEO compensation, director compensation, and firm performance: Evidence of cronyism?. Journal of Corporate Finance, 12(3), 403-423.

Burkia, A. A., \& Ahmadb, S. (2010). Bank governance changes in Pakistan: Is there a performance effect?. Journal of Economics and Business, 62, 129-146.

Choe, H., \& Lee, B. S. (2003). Korean Bank Governance reform after the Asian Financial crises. Pacific- Basin Finance Journal, 11(4), 483-508.

Čihák, M., \& Hesse, H. (2010). Islamic Banks and Financial Stability: An Empirical Analysis. J Financ Serv Res, 38, 95-113.

De Nicolo’, G. (2000, December). Size, Charter Value and Risk in Banking: An International Perspective. International Finance Discussion Papers 689, Board of Governors of the Federal Reserve System.

Ezzeddine, A., Chourou, L., \& Saadi, S. (2008, February). The economic determinants of CEO. Journal of Multinational Financial Management, 18(1), 61-77.

Fadzlan Sufian et Muzafar Shah Habibullah. (2010, December). Does economic freedom foster banks' performance? Panel evidence from Malaysia. Journal of Contemporary Accounting \& Economics, 6(2), 77-91.

Florackis, C., \& Ozkan, A. (2008, January). Agency costs and corporate governance mechanisms: Evidence for UK firms. International Journal of Managerial Finance.

Foroughi, M., \& Fooladi, M. (2012, March). Concentration of Ownership in Iranian Listed Firms. International Journal of Social Science and Humanity, 2(2).

Ghaffar, A. (2014). Corporate Governance and Profitability of Islamic Banks Operating in Pakistan. Interdisciplinary Journal of Contemporary Research in Business, l6(2).

Gujarati, D. N. (2003). Basic Econometrics. New York: McGraw Hill Book Co.

Htay, S. N. N., Said, M., Ridzwana, S., \& Ahmed, S. (2013). Impact of corporate governance on disclosure quality: empirical evidence from listed banks in Malaysia. International Journal of Economics and Management, 7(2). 242-279.

Htay, S. N. N., Said, R. M., \& Salman, S. A. (2013). Impact of Corporate Governance on Disclosure Quality: Empirical Evidence from Listed Banks in Malaysia. Int. Journal of Economics and Management, 7(2), 242-279.

Huther, J. (1997, July). An empirical test of the effect of board size on firm efficiency. Economics Letters, 54(3), 259-264. 
Kennedy. (2003). A Guide to Econometrics. Econometrics. Retrieved from https://mitpress.mit.edu/books/guide

Korac, N., Kakabadse, A. K. K., \& Kouzmin, A. (2001). Board governance and company performance: any correlations?", Corporate Governance. The International Journal of Business in Society, 1(1), 24-30.

Krivogorsky, V. (2006). Ownership, board structure, and performance in continental Europe. The International Journal of Accounting, 41(2), 176-197.

Kukreja, G. (2013). Impact of New Corporate Governance Code on Disclosures: Evidences from Bahraini Listed Commercial Banks. Advances in Management \& Applied Economics, 3(3), 171-191.

Kula, V. (2005). The Impact of the Roles, Structure and Process of Boards on Firm Performance: evidence from Turkey. Corporate Governance: An International Review.

Lee, S.P., Isa M. (2015). Directors' remuneration, governance and performance: the case of Malaysian banks. Managerial Finance, 41, 26-44.

Liang, Q., Li, X., Yang, X., Lin, D., \& Zheng, D. (2013). How does family involvement affect innovation in China. Asia Pacific Journal of Management, 30(3), 677-695.

Matoussi, H., \& Grassa, R. (2012). Is Corporate Governance Different for Islamic Banks? A Comparative Analysis Between the Gulf Cooperation Council Context and the Southeast Asia Context. Working Paper 734. The Economic Research Forum (ERF).

Mohd Danial Afiq Khamar Tazilah et Rashidah Abdul Rahman. (2014). Risk Management \& Corporate Governance Characteristics in the Malaysian Islamic Financial Institutions. Research Journal of Finance and Accounting, 5(12).

Praptiningsih, M. (2009). Corporate Governance and Performance of Banking Firms: Evidence from Indonesia, Thailand, Philippines, and Malaysia. Journal Manajemen Dan Kewirausahaan, 11(1), 94-108.

Rabi, N. M., Zulkafli, A. H., \& Haat, M. H. C. (2010). Corporate governance, innovation investment and firm performance: evidence from Malaysian public listed companies. Economia. Seria Management, 13.

Rahman, A. A., \& Bukair, A.(2013). The influence of the Shariah supervision board on corporate social responsibility disclosure by Islamic banks of Gulf Co-operation Council countries. Asian Journal of Business and Accounting, 6(2).

Ramiz Ur Rehman et Inayat Ullah Mangla. (2010). Corporate Governance and Performance of Financial Institutions in Pakistan: A Comparison between Conventional and Islamic Banks in Pakistan. Pakistan Development Review, 49(4), Winter, 969.

Rebeiz, K., \& Salameh, Z. (2006). Relationship between Governance Structure and Financial Performance in Construction. Journal of Management in Engineering (ASCE), 22, 20-26. 


\section{Macrothink}

International Journal of Accounting and Financial Reporting ISSN 2162-3082 2018, Vol. 8, No. 3

Shawki, B. A., \& Gharbi, A.H. A. (2014).The impact of the applying corporate governance rules on the performance of Islamic banks: An Empirical Study. Journal for Economic Development Algeria.

Sheikh, N. A., \& Karim, S. (2015). Effects of internal governance indicators on performance of commercial banks in Pakistan. Business and Economic Research, 4(1).

Sulaiman, B. (2005). The Impact of Investment and Financial Intermediation on Economic Growth: New Evidence from Jordan. International Research Journal of Finance and Economics, 14.

Tomar, S., \& Bino, A. (2012). Corporate governance and bank performance: Evidence from Jordanian Banking Industry. Jordan Journal of Business Administration, 8(2).

Zied, C., \& Pluchart, J. J. (2006). La gouvernance de la banque islamique. Retrieved from https://ribh.files.wordpress.com/2008/01/la-gouvernance-de-la-banque-islamique.pdf

\section{Copyright Disclaimer}

Copyright for this article is retained by the author(s), with first publication rights granted to the journal.

This is an open-access article distributed under the terms and conditions of the Creative Commons Attribution license (http://creativecommons.org/licenses/by/4.0/) 